\title{
Problem Solving Skills and Learning Achievements through Problem-Based Module in teaching and learning Biology in High School
}

\author{
Wan Syafii ${ }^{1} \&$ Ruhizan Mohd Yasin ${ }^{2}$ \\ ${ }^{1}$ Faculty of Education, University of Riau, Indonesia \\ ${ }^{2}$ Faculty of Education, Universiti Kebangsaan Malaysia, Selangor, Malaysia \\ Correspondence: Wan Syafii, Faculty of Education, University of Riau, Indonesia. E-mail:
} wansya_ws@yahoo.com

Received: August 1, 2013 Accepted: August 16, 2013 Online Published: August 30, 2013

doi:10.5539/ass.v9n12p220 URL: http://dx.doi.org/10.5539/ass.v9n12p220

\begin{abstract}
The purpose of this study was to examine the effects of using problem-based module (PBM) in the subject of Biology on high school students' problem-solving skill and achievement. This research used the quasi-experiment method with Non-Equivalent Pretest and Posttest Control Group Design, which involved two science classes, in which one group was assigned as control group and another one as experiment group, in a high school in Pekan Baru, Indonesia. The problem-solving ability and the product of learning were descriptively analyzed before being inferentially analyzed. To find out whether or not there is any difference in their problem-solving skill, t-Test and N-gain test was conducted on the experimental group's and control group's concept mastery level and product of learning. The result shows that the problem-solving skill percentage of the experimental group was $95.47 \%$ (very good), whereas that of the control group was $25.12 \%$ (low). The average of student's achievement in the experimental group was $84.26 \%$ (good), while that of the control group equaled $79.08 \%$ (moderate). The average of the product of learning was $89.89 \%$ (good) for the experimental group, whereas that of the control group was $52.10 \%$ (low). The findings showed that PBM can actually increase problem-solving skill, students' achievement, and students' learning product, with the experimental group getting higher percentage in all three aspects compared to the control group by using PBM in their Biology class. The implication of this study is the increase in the quality of learning through learning innovation using learning module. The panned and organized implementation of this module by teachers will not only improve students' thinking skills, but also increase the quality of science and technology, consistent with the aim of Indonesia education.
\end{abstract}

Keywords: problem-based module, biology, problem-solving skill, student's achievement

\section{Introduction}

Biology is a branch of science that is related to the systematic study of the nature. Rather than just being a way of mastering a set of knowledge in the form of facts, concepts and principles, Biology is also regarded as a process of discovering knowledge. In general, Biology is taught in schools so that students can fully understand the concepts and apply them to solve related problems, at the same time appreciating God's power and creation. Realizing how important the subject is, teachers should choose the correct methods and techniques in optimizing students' involvement in the class for a more meaningful learning process.

Therefore, a sense of innovation is needed in the teaching and learning of Biology to increase the quality of the education. This innovation process can be done by using a certain learning model that can assist students in improving their problem-solving abilities and concept mastery so that they can apply that knowledge in a real-life situation. One of the innovations is the problem-based learning model (PBM).

There are two reasons for the usage of PBM, that is, to maximize or increase the memory retention and to ensure that the information transfer is not just in the form of knowledge (Punaji Setyosari, 2009)

According to Ibrahim and Nor (2002), Ismail (2002), and Chin and Chia (2004), PBM model is made up of five main levels: (1) Introducing students to the problem by the teacher. (2) Organizing students for the lesson. (3) 
Guiding and facilitating individual or group research. (4) Building and presenting the findings. (5) Analyzing and evaluating the whole problem-solving process.

In PBM, students are responsible of their own learning and are required not to depend too much on their teacher. PBM creates students who are independent and can continue to have a lifelong learning on their own. Teachers act more like a tutor or a facilitator to guide students through the learning process. As students progress, teachers' guidance will become less and less. PBM learning process is due to the complexity of the problems in the real world. This fact is used by teachers and learners alike as a motivation to use and integrate the information that they obtain, to remember and apply it so that they can solve the problems that they will face in the future. PBM was designed to challenge students to optimize their creative and critical thinking skill (CCTS) and effectively solve problems (Kiranawati, 2007).

PBM was designed to prepare students to relate the content of the lesson to the real world situation, and solve problems through activities and investigations based on the theories, concepts and principles that they have learned (Chin \& Chia, 2004; Evi Suryawati, 2006; Shipra Vaidya, 2009; Ibrahim \& Nur, 2002). It was also designed to help students develop the thinking and communication skills to succeed (Duch \& Groch, 2001), while the unstructured problems in PBM help them to increase their cognitive process and improve their reviewing skills (Chin \& Chia 2005) and also help them to be able to fulfill the demand caused by the era of information technology and globalization (Mohd Ali, 2008). Through this method, real life problems can be presented to students in a relevant way. Students actively participate in groups to solve problems as teachers just act as a facilitator in the construction of their knowledge. Teachers centralize their attention to helping students to achieve the self-directed learning skill (Pasek 2008). This method encourages active learning and fosters critical, reflective and receptive thinking (Desmita, 2006; Liliasari, 2000; Nabishah et al., 2009) and students are able to know what and why they are learning what they are learning in the construction of their knowledge (Chin \& Chia, 2004). Graduates from PBM School also possess better interpersonal, problem solving, independent learning and information accessing skill. According to a research done by Simranjet (2010), PBM integrated with ICT can have more positive impact on the Biology subject, especially in generic skills such as problem solving skill, communication skill and student's attitude. Natrah Mohamad (2012) stated that PBM impacts beginner and advanced learners differently, and also it can lessen the gap that exists between these two groups, thus helping the beginner learners to learn better.

\section{Statement of the Problem}

This research focused more on the issue of teachers, trained in either national or Riau district level, who still use conventional way of teaching like lectures in which the lesson is still centralized and dominated by the teacher, causing students to become passively involved. This causes students to feel like learning Biology is nothing but memorizing notes. Students' learning outcomes are more focused on the cognitive ability rather than the process. In some schools, the teachers even ignore some of the competency-based contents provided in the text book and less attention is given to problem solving skills. Teachers are still unable to create a lesson that could actively involve students in the learning process. Based on the current scenario of the science education, researcher of the current study has felt the need to examine the implementation of PBM in a way that has been entrusted by the government.

\section{Literature Review}

\subsection{Problem-Based Learning Model (PBM)}

PBM is a learning model that is used to stimulate students' thinking to a higher level, and centralize around real-world problems which include learning how to learn (Ibrahim \& Nur, 2002). This accords with the recommendation made by the College of Education, University of Washington (2001), which stated that the usage of real-life problems as a context for students' thinking can help them not only solve problems, but also grasp the essential knowledge and concepts. PBM is also one of the lesson techniques that can be taught using the Contextual Learning Model.

Chin and Chia (2004) put forth the idea of five steps in implementing PBM, adapted from Sharan and Sharan (1989), which includes: (1) Identifying the problem studied (2) exploring the scope of the problem (3) guiding students in doing scientific research (4) combining the findings, and (5) presenting the findings, evaluation by teachers and self-reflection. These five levels are all problem-based.

However, Ibrahim and Nur (2002) and Ismail (2002) have introduced another five main levels of PBM, adapted from Arends (1997): Teacher (1) introduces students to problem, in which teacher explains the objectives of learning, the materials needed and motivates his/her students (2) Organizes students for the learning, in which 
teacher helps them define and organize the learning task (3) Guides individual or group research, in which teacher guides the students to collect the suitable information, carry out the research to obtain the answer and solve problem (4) Builds and presents findings, in which teacher helps the students to document their research in the form of report etc, and (5) Analyzes and evaluates problem-solving process, in which the teacher helps the students to do a reflection and evaluate their research and the process they used.

PBM does not suggest that teachers provide as much input for their students as they can. Instead, the idea behind PBM is to help students to boost their thinking, problem-solving and intellectual skills, like learning what it feels like to be a grownup through simulation and role-playing.

Problem-solving skill is one of the basic skills, which needs to be nurtured in students. This skill can be developed through practice (Susilo, 2003) so that students can be trained at a higher level to have excellent thinking skills, and be able to justify with proofs and find other alternatives to solve problems (Browne \& Keeley, 1990). According to Ruggiero (1988), thinking is a mental activity that can help round up and solve problems and make decisions. In other words, to think is to find answers to questions in order to achieve some sort of understanding regarding a concept and meaning. Problem solving is the highest and more complex level of learning. The thinking process in problem solving requires skills to process and organize the obtained information to utilize it in the problem solving process. Possessing a problem solving skill means that the person is able to think critically, logically and creatively.

Mastering a concept or learning content is very significant in the continuity of a learning process. The ability to fully understand and master a concept is the fundamental often used by educators in carrying out the learning process. The learning process will be much smoother once the students are able to grasp the mastery (Syah, 2006). The mastery of concept in Biology lesson can be measured by a test and the result can be known by the number of technical questions that are answered correctly. Sudijono (2003) stated that cognitive evaluation is the perfect measuring device for knowing the level of understanding that an individual has towards the mastery.

\section{Research Objectives}

This research was carried out to examine the effectiveness of problem-based module on students' problem-solving skills, achievement, and product of learning after the teaching and learning session are done.

\section{Methodology}

This study was conducted in one high school in Pekanbaru involving participants from two classes, where one group was assigned as control group and another one as experiment group. Quasi-experiment method was chosen with Non-Equivalent Pretest and Posttest Control Group Design, modified and simplified as shown in the table below:

Table 1. The design of the quasi-experiment study

\begin{tabular}{|c|c|c|c|}
\hline Group & Pre-test & Treatment & Post-test \\
\hline Experimental (E) & O.1 & $X$ & 0.2 \\
\hline Control (C) & O.1 & - & 0.2 \\
\hline $\mathrm{E}:$ Treated group ( & skill using & & \\
\hline Control group & & & \\
\hline : Treatment: lear & 1 using PB & & \\
\hline O.1 : Pre-test & & & \\
\hline O.2 : Post-test & & & \\
\hline
\end{tabular}

The treatement group used the PBM in learning problem-solving skills with teacher's guidance. They used the PBM module as a guide in their teaching and learning session. Students are required to carry out the learning activities according to the task and activity sheets that contain problem solving activities and spaces that indicate the main steps in implementing PBM. Throughout theintervention, teachers acted as facilitator while students' learning activity was observed structurally using the obseravation sheet to monitor problem-solving skill mastery progress. The controlled group has learnt their Biology lesson using the conventional method of teaching, in which the teacher used the available lesson plan. The teaching method involved lectures and drills. Students used Biology text book and other reference books to guide them in the process of learning. Moreover, students also 
carried out activities according to the syllabus. Students were not exposed whatsoever to the PBM model. Just like the treated group, they were also observed and their progress was monitored.

The indicators used in the observation include: (1) The ability to identify problems (2) The ability to gather datas (3) The ability to plan the solution (4) The ability to execute the plan to solve problem, and (5) The ability to evaluate the problme-solving process. The post-test was carried out after the T\&L session to test the ability of students from both the treated and the control group.

The data is presented in both qualitative and quantitative form. Qualitative data was obtained form the observation sheet, which was quantified, whereas the quantitative data was obtained from the pre and post test. Data was analyzed using the SPSS software 18. Problem-solving ability and learning product were first analyzed descriptively, and then inferentially. To find out whether or not there is a difference in problem-solving skill, the achievement in mastering the concept and learning products between the experimental and control group was tested using t-test and $\mathrm{N}$-gain.

\section{Results and Discussion}

\subsection{The Effect of PBM on Learner's Problem-Solving Skill}

The average of the percentage of learners from the control and treatment group's problem-solving skill is as shown in the table below:

Table 2. The average percentage of problem solving abilities of SMAN 1 Pekanbaru students from the control and experimental group

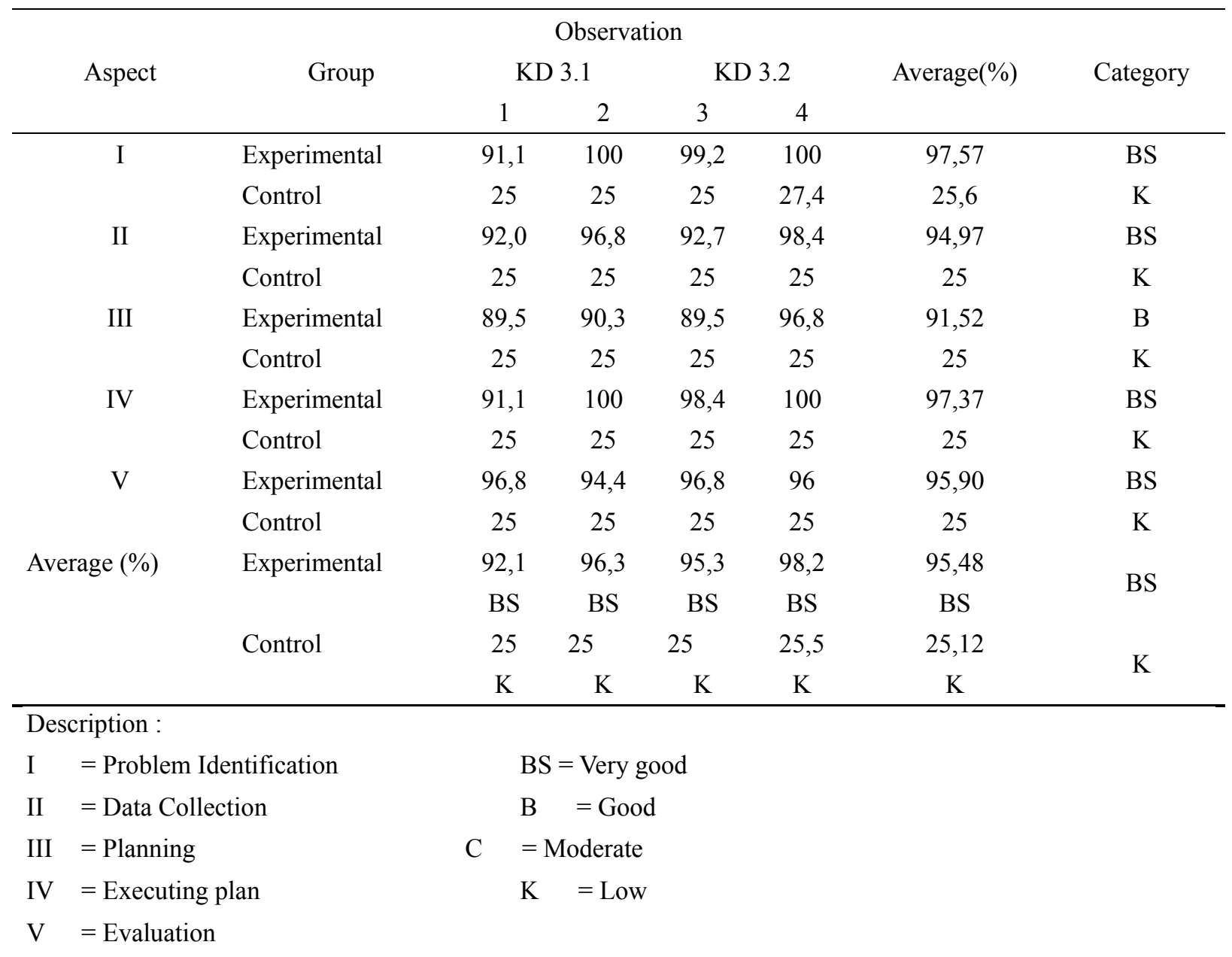

KD 3.1 =Explaining the connection between the structure, function, process and the difference between the disease that can attack human muscle system.

KD 3.2 = Explaining the connection between the structure, function, process and the difference between the disease that can attack human circulatory system. 
Table 2 shows that there is a significant difference in students' problem solving abilities from both groups. The average percentage for the experimental group is higher (95.47\%) than that of the control group $(25.12 \%)$. This is because the lesson conducted for the control group was not directed towards problem solving activities and the aspects of problem solving. All the inputs were received from the teacher and students were not actively involved in the learning process. The experimental group, on the other hand, using the PBM model, was exposed to real-life problems and was required to solve them using sources such as books, internet and group discussion.

This means, through using PBM, students can experience problem solving themselves and this experience would hopefully one day assist them in facing the real world by applying the knowledge and steps that they have learned. Amir (2009) stated that the knowledge that you gain through self-discovery is more meaningful and is easier to apply in real life compared to the one you get from lectures or other people's explanation. In the same line, Trianto (2009) stated that trying to solve problems on your own makes the experience and knowledge more worth it.

To find out the difference between problem solving ability of the experimental and the control group, a t-Test was conducted and the findings can be seen in Table 3:

Table 3. t-Test on the differences of problem solving ability between the experimental and the control group

\begin{tabular}{lcc}
\hline \multicolumn{1}{c}{ Group } & Problem solving ability (\%) & Category \\
\hline Experimental & 95,48 & $\mathrm{~B}$ \\
Control & 25,12 & $\mathrm{~K}$ \\
$\mathrm{t}_{\text {total }}$ & $114.68^{*}$ & \\
$\mathrm{t}_{\text {table }}$ & 2,0 & \\
\hline Ket: $*$ significant & &
\end{tabular}

It can be seen from Table 3 that the problem solving ability of the experimental and control group differs significantly.

Using PBM model, students are trained to solve problems on their own, and teachers only act as a facilitator, introducing students to the problem and facilitating students' discussion and learning. Wayan Subagja (2003) stated that PBM is an innovative learning model that can act as a platform for students to be active in their learning. PBM allows students to solve problems using scientific method up to the point that students can learn something that is related to the problem. Crawford (2001) stated that problem solving can give students the experience of learning and increase their creativity in learning important concepts. Problem solving could also increase analytical thinking skills and communication and interaction within groups. Allen (2006) stated that the real-life problem solving skills provided by PBM can increase learner's motivation and learning could happen contextually and be useful, based on learner's basic knowledge. Somez and Lee (2003), on the other hand, stated that PBM challenges students to make efforts and try to solve the problems on their own and the stress is put on them or the group they are in. PBM promotes self-learning. The problems are guaranteed to trigger learner's curiosity by relating it to real-life situation.

\subsection{The Effect of PBM in the Level of Concept Mastery}

To find out how well the students in both groups master their concepts, an N-gain test was conducted. The comparison of the results of the N-Gain test, per test and post test of both group are repsresented in the form of bar chart below. 


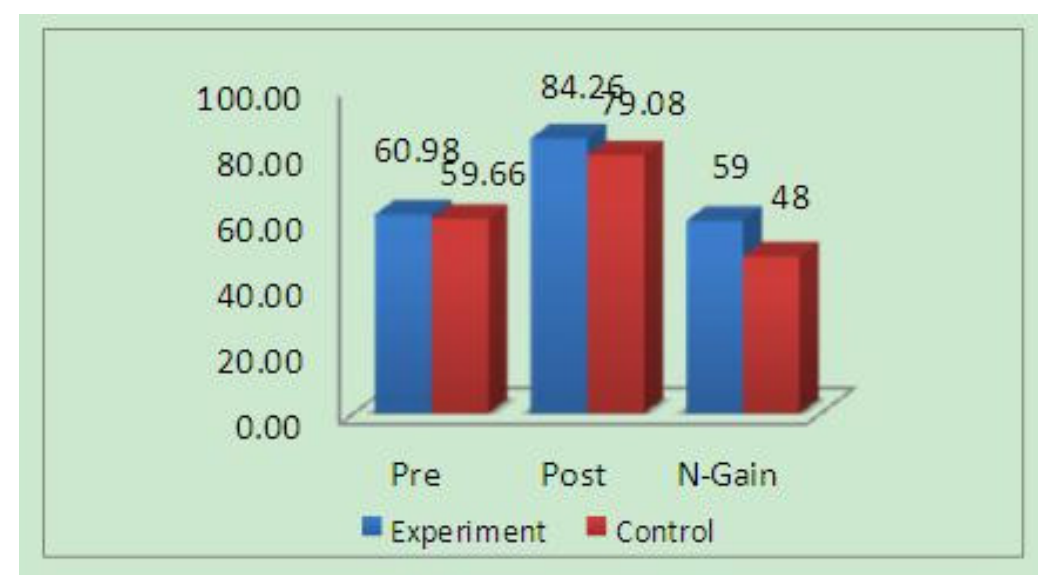

Figure 1. Students' level of concept mastery

From the bar chart, we can see that the scores for the pre and post test are higher for the experimental group (60.98 \& 84.26 respectively) compared to the control group (59.66 \& 79.08 respectively). This also affects the $\mathrm{N}$-Gain result in which the experimental group scores a mark of 59, while the control group scores 48 . This is caused by the PBM implementation in the experimental group's lesson that focuses on problem-solving, active participation from the learners to understand the thing that they are learning and connect them with the problems they are about to solve, hence the self-learning and ability to construct one's own knowledge.

To find out the difference between concept mastery level of the experimental and the control group, a t-Test was conducted and the findings can be seen in Table 4:

Table 4. t-Test on the differences of concept mastery level between the experimental and the control group

\begin{tabular}{|c|c|c|}
\hline Group & Concept mastery & Category \\
\hline Experimental & 84.26 & B \\
\hline Control & 79.08 & $\mathrm{C}$ \\
\hline$t_{\text {total }}$ & $2,58^{*}$ & \\
\hline$t_{\text {table }}$ & 2,00 & \\
\hline
\end{tabular}

Table 4 shows that there is a significant difference between the treatment and control groups in terms of their mastering concepts. It can be said that PBM has a great potential in increasing learner's mastery of concept through active participation and involvement in learning to solve the problems prepared by the teachers. Amir (2009) stated that PBM can help students to be more efficient in solving problems, improving memory, increasing understanding, and building up knowledge relevant to the practical world.

\subsection{The Effects of Using PBM Module on Learning Products/Achievement}

Table 5 shows learners' learning product/achievement by combing the problem solving ability with the value of post test. 
Table 5. t-Test on the differences of the learning products between the experimental and the control group

\begin{tabular}{ccccc}
\hline Group & $\begin{array}{c}\text { Problem Solving Skill } \\
(50 \%)\end{array}$ & $\begin{array}{c}\text { Concept Mastery } \\
(50 \%)\end{array}$ & $\begin{array}{c}\text { Learning Product/ } \\
\text { Achievement }\end{array}$ & Ket \\
\hline Experimental & 44,93 & 42,13 & 89.87 & Good \\
Control & 12,56 & 39,54 & 52.10 & Low \\
$\mathrm{t}_{\text {total }}$ & & & $34.36^{*}$ & \\
$\mathrm{t}_{\text {table }}$ & & & 2.00 & \\
\hline
\end{tabular}

Ket: $*=$ significant

The experimental group can be seen to have achieved more than the control group with the score of 89.89 (good), while the control group scored 52.04 (low). The t-test result also shows that there is a significant difference in both group's achievement.

All in all, a lesson teaching will produce better learning products if it is both product and process-oriented. PBM focused on problem solving, in which students try on their own to solve the problems submitted using the concepts that they have learned and to connect their knowledge in order to solve the problems. A research done by Corner and Gustone (2004) and Mohd Ali (2008) shows that learning process is supported by the strategies used by learners in solving a learning task. This enables learners to understand the learning process en route in becoming a learner who is able to actively direct, monitor and evaluate his/her learning process. Trianto (2009) stated that PBM helps learners to discover and construct the knowledge themselves, through connecting it to their prior knowledge. Johnson (2006) stated that PBM improve learner's intellectual potential by teaching them the steps in thinking critically and creatively on a higher level in the context of a real world. In other words, science is not all about the intellectual aspects, but also stresses on the ability to think creatively on a higher level using various learning strategies, with teachers creatively coming up with a lesson to create the required environment to foster such learning.

\section{Implications and Recommendation}

The study shows that using PBM can help improve learner's problem solving skills and their achievement in the subject of Biology. The level of problem-solving ability, achievement and learning product can be seen higher in the experimental group compared to the control group.

This study also recommends that teachers use the problem-based module in teaching Biology. The positive impact of this study can encourage teacher to imply more problem-based content in their lesson and classroom activities. This study has succeeded in showing that PBM has a very high content and design validity and reliability. In fact, this module can be used as an aid in increasing learner's motivation and help teachers smoothen the teaching and learning process in the classroom.

Likewise, this study may also help increase the quality of education through the innovation of learning by preparing learning module. If teachers implement this method with organization and good planning, it will not only improve students' thinking skill, but also increase the quality of science and technology in Indonesia, consistent with the aim of national education in Indonesia. Moreover, further study is recommended to examine the efficiency of this module experimentally. Studies to be conducted in the future will hopefully use more than on treated group and consider the timing, as lack of time is considered to be the limitation of this study.

\section{Conclusion}

The PBM approved to help the students to achieve academic excellence especially for the biology subject. Furthermore, this PBM can be applied in the other teaching methods in the other subjects as well. The teachers in the schools should be expert to employ PBM in the process of teaching and learning appropriately in the classroom. This is because PBM has already proved to be one of the best approaches in teaching.

\section{References}

Allen, D. (2006). Problem based learning in undergraduate science. Project Kaleidoskop, (IV). Retrieved July 20, 2009, from http://www.mis4.udel.edu/Pbl

Amir. (2009). Inovasi Pendidikan Melalui PBL. Kencana Predana Media Grup. Jakarta.

Arends, R. I. (1997). Classroom Instructional and Management. New York: MCGraw-Hill. 
Browne, M. N., \& Keeley, S. M. (1990). Asking the Right Question: A Guide to Critical Thinking. Edisi ke-3. New Jersey: Prentice Hall.

Campbell, D. T., \& Stanley, J. C. (1963). Experimental and quasi-experimental designs for research. Chicago: Rand McNally \& Co.

Chin, C., \& Chia, L. (2004). Implementing project work in biology through: Problem based learning. Journal of Biological Education, 38(2), 69-75. Retrieved February 14, 2007, from http://www.lob.org/downloads/277.pdf http://dx.doi.org/10.1080/00219266.2004.9655904

Chin, C., \& Chia, L. (2005). Problem-based learning: using III-structured problems in biology project work. Wiley Interscience. Retrieved from http://www.Interscience.wiley.com

Conner, L., \& Gunstone, R. (2004). Conscious knowledge of learning: accessing learning strategies in a final year high school biology class. International Journal of Science Education, 26(12), 1427-1443. http://dx.doi.org/10.1080/0950069042000177271

Crowford, M. L. (2001). Teaching Contextually: Research, Rationale, and Techniques for improving Student Motivation and Achievement in Mathematics and Science. Texas: CORD.

Desmita. (2006). Psikologi perkembangan. Bandung: Remaja Rosda Karya.

Duch, B. J., \& Groh, S. E. (2001). Winter.The power of problem-based learning ini teaching introductory science courses. New directions for teaching and learning, (68).

EviSuryawati. (2006). Peningkatan kualitas pembelajaran biologi melalui pembelajaran berbasis masalah (Problem-Based Learning). Proseding Seminar Nasional Pendidikan IPA 2006: Bandung. UPI.

Ibrahim, M., \& Nur, M. (2002). Pembelajaran berdasarkan masalah. Surabaya: UNESA University Press.

Ismail. (2002). Pembelajaran berdasarkan masalah (problem based Instruction). Makalah disajikan pada pelatihan TOT Pembelajaran Kontekstual. Surabaya.

Johnson, E. B. (2006). Contextual Teaching \& Learning: Menjadikan Kegiatan Belajar- Mengajar Mengasyikkan dan Bermakna. In T. I. Setiawan, \& I. Sitompul (Eds.). Bandung: Mizan Learning Center (MLC).

Judge, S. K., Osman, K., \& Yasin, S. F. (2010). Kesan Pembelajaran Berasaskan Masalah Berasaskan TMK ke atas Pencapaian, Sikap, Kemahiran Komunikasi dan Menyelesaikan Masalah pelajar dalam Mata pelajaran Biologi. Prosiding Seminar Penyelidikan Siswazah. Universiti Kebangsaan Malaysia.

Kiranawati. (2007). Pembelajaran Berdasarkan Masalah. Retrieved January 24, 2013, from http://unisys.uii.ac.id/index.asp?

Liliasari. (2000). Pengembangan keterampilan berpikir kritis untuk mempersiapkan calon guru IPA memasuki era globalisasi. Seminar Nasional Pengembangan Pendidikan MIPA di Era Globalisasi.

Mohamad, N. B. (2012). Kesan Pembelajaran Berasaskan Masalah Terhadap Pencapaian dan Pemikiran Kritikal dalam Topik Nutrisi. Tesis Sarjana Pendidikan. Fakulti Pendidikan, Universiti Kebangsaan Malaysia

Mohamad, N., Suhaimi, F. H., Das, S., Salam, A., Bujang, S. M., Kamarudin, M. A., ... Wan Zurinah, W. N. (2009). Problem-Based Learning Facilitation: New Challenges to Higher Education Educators. International Medical Journal, 16(4), 243-246.

Pasek, I. N. (2008). Pembelajaran Berbasis Masalah (Problem Based Learning). Minggu, 20 April 2008.

Ruggiero, V. (1988). Teaching Thingking Across the Curriculum. New York: Harper \& RowSalkind, N. J. 2000. Exploring research (4th ed.). Upper Saddle River: Prentice Hall.

Samsudin, M. A. (2008). Kesan penggunaan perancahan kognitif dalam pembelajaran berasaskan masalah terhadap metakognisi, penaakulan santifik dan pencapaian pelajar dalam mata pelajaran Fizik tingkat empat. Thesis Dr. Falsafah. Universiti Kebangsaan Malaysia.

Setyosari, P. (2009). Belajar Berbasis Masalah (Problem-Based Learning). Retrieved January 25, 2010, from $\mathrm{http} / / /$ tep.ac.id/berita-106-belajar-berbasis-masalah---problembased-learning.html

Sonmez, D., \& Lee, H. (2003). Problem based learning in science ERIC clearinghouse for science mathematics and environmental education Columbus $\mathrm{OH}$. Retrieved April 4, 2008, from http://www.vtaide.com/png/ERIC/PBL-in science/html

Subagia, I. W. (2003). Masalah-masalah penerapan model pembelajaran sains dengan pendekatan starter 
eksperimen (PSE) dalam pembelajaran sains di sekolah. Jurnal Pendidikan dan Pengajaran IKIP Negeri Singaraja, 4(36).

Sudijono. (2009). Pengantar Statistik Pendidikan. PT. Raja Grafindo. Jakarta.

Susilo, H. (2003). Kapita Selekta Pembelajaran Biologi. Jakarta: Pusat Penerbitan Universitas terbuka.

Syah, M. (2006). Psikologi Pendidikan dengan Pendekatan Baru. Edisi Revisi. Bandung PT. Remaja Rosdakarya.

Trianto. (2009). Mendesain Model Pembelajaran Inovatif Progresif. Kencana Prenada Media Group. Jakarta.

University of Washington: College of Education. (2001). Training for Indonesian Team Individu-Individu Cintextual Teaching and Learning. Seatle.

Vidya, S. (2009). The Problem-based Learning Model for Teaching Entrepreneurship. In O.S. Dlm. Tan (Ed.), Problem-based Learning and Creativity. Singapore: Thomson Asia Pte Ltd.

Wiersma, W. (1991). Research methods in education: An introduction. Boston: Allyn \& Bacon.

\section{Copyrights}

Copyright for this article is retained by the author(s), with first publication rights granted to the journal.

This is an open-access article distributed under the terms and conditions of the Creative Commons Attribution license (http://creativecommons.org/licenses/by/3.0/). 